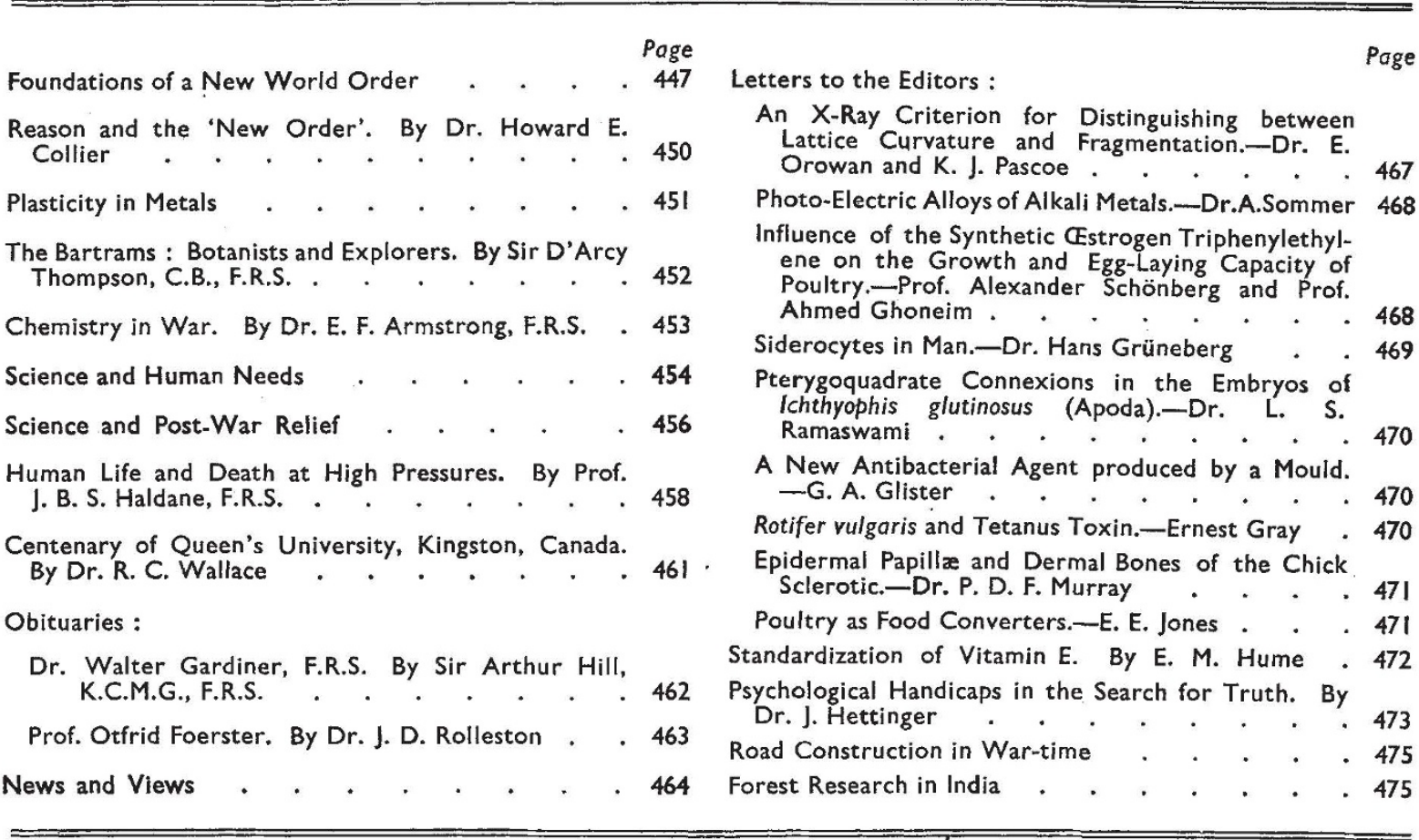

\title{
FOUNDATIONS OF A NEW WORLD ORDER
}

$\mathrm{T}$ HE Atlantic Charter has rightly been recognized as a political offensive of the first order. It is the starting-point for far-reaching and greatly intensified political warfare. Even more important, there is scarcely one of the eight points that is not a challenge to clear, fundamental and constructive thinking. That in certain respects most of the eight points require elaboration, if not elucidation, does not detract from the significance and value of the charter they constitute.

The many attempts already made to outline the basis of a new order which affords an adequate reply to that which the Nazis seek to impose on a prostrate Europe must therefore be given careful consideration. Two such recent efforts may be commended to the attention of scientific workers for their contribution to clear and constructive thinking. The first of these, by Prof. E. H. Carr, in the Democratic Order series of pamphlets*, deals particularly with the issues involved in the principle of self-determination and nationality, and should help to clarify thought about the second and third points of the Charter. The second, Mr. C. B. Purdom's "The New Order" $\dagger$,

* The Future of Nations: Independence or Interdependence? By E. H. Carr. (The Democratic Order, No. 14.) Pp. 64. (London: By E. H. Carr. (The Democratic Order, No.

† The New Order. By C. B. Purdom. Pp. xvi +286. (London: J. M. Dent and Sons, Ttd., 1941.) 78. 6d. net. goes even deeper into the social and economic changes involved in the establishment of any new order which worthily embodies the ideas of the fourth, fifth and sixth points of the Charter.

Prof. Carr's pamphlet derives its main value from its critical exposition of some of the fallacies which have initiated policy in the past, although he concludes with various constructive suggestions. $\mathrm{He}$ directs attention to the limited validity of the supposed coincidence between the principle of nationality and that of self-determination. Generally speaking, this is valid only for the limited area of western Europe, and self-determination should accordingly be carefully disentangled from those misleading associations with nationalism which nineteenth-century thought fastened upon it. It rnust be recognized in future that the selfdetermination of small nations is incompatible with unbridled economic power and complete economic independence.

Furthermore, Prof. Carr points out that the development of military technique and the conditions of modern warfare have broken down the conception of the independence of small States based on the principle of self-determination. In modern conditions of warfare, a small State cannot defend its independence against a great Power except by methods which in themselves constitute 
a surrender of military independence. Interdependence has become an inescapable military necessity. Neutrality has been virtually nullified for small nations in proximity to the theatre of war, both in the military and in the economic sphere. The small Power can in fact only survive by seeking the permanent alliance of a great Power.

Prof. Carr maintains that the failure of the settlement of 1919 was due, first to disregard of the economic factor, and secondly to neglect of the way in which military conditions had thus qualified self-determination. Moreover, many factors already introduced in the present War tend further to complicate the question of self-determination and independence. The offer of Great Britain to form a union with France, and also the Atlantic Charter, are the most striking examples of the extent to which nations have been prepared for close military and economic co-operation for the tasks of peace. The Inter-Allied meetings in London, a composite army, a navy and an air force in which units of different nationalities are embodied under a single command, the possession by one country of naval or air bases on the territory of another-all these are arrangements which need not disappear with the war. The Eight Points show that the democratic leaders have no intention of returning to the anarchy and confusion that marked the life of the world between the two wars.

Tentatively, Prof. Carr concludes, therefore, that we must discard the nineteenth-century assumption that nation and State should normally coincide, and lay far less stress on the absolute character of the right of self-determination and far more on its necessary obligations. Neglect of these correlative obligations was one of the cardinal errors of 1919, and Prof. Carr indicates how from this flow two lines of development towards international order : recognition of the need for a larger unit than the present nation for military and economic purposes and, within this unit, for the largest measure of devolution for other purposes, and recognition that the right of national self-determination can be valid only within the limits of this necessity for military and economic concentration.

Acceptance of these principles clearly involves a revolution in our whole thinking about neutrality, economic policy and defence, and that revolution must commence before the fighting ends. The lines of policy suggested by Prof. Carr are in fact well calculated to gain time for such a transformation of thought to occur. First, he urges the vital importance of maintaining, for the organization of peace, the forms of co-operation already established by those united in the struggle against Nazism. This machinery of interdependence and co-operation should be extended to other countries by an empirical process based on practical needs and possibilities. In the same way the constitutional forms of such co-operation must be determined, not theoretically according to some a priori conception of league, alliance or federation, but empirically as the outcome and expression of a practical working arrangement. The establishment and maintenance of de facto co-operation are far more important than the drafting of constitutional rules to regulate. At the present stage, interdependence is the practical problem of surrendering the habit of framing our military and economic policy without regard for the needs and interests of other countries.

In spite of the entirely different approach, Mr. Purdom's much more ambitious study gives a strikingly similar outline of a new order. The greater part of his book is indeed occupied by a comparatively detailed outline of a new order in Britain, but like Prof. Carr, he insists in the first place on the need for a new attitude, for a revolution in thought and the readiness to sacrifice old prejudices and ways of thought and living. The new order he outlines is built up of nations or States in which this changed outlook has already occurred, and the evolution of international institutions, whether in Europe or in the world at large, proceeds from the nation as model and as unit.

The structure of the new order conceived by Mr. Purdom is association in the State, society and nation, and it is to be built up through the recognition of the functional principle. International co-operation becomes practicable through the creation of functional organs within the nation and through the removal of sovereign power. The conversion of the British State into a functional organ involves the separation of economic and cultural from civic and political objects, those functions of the State now concerned with industry and trade being entrusted to an economic organ and those concerned with education, health, art and science to a cultural organ. The State would then be concerned strictly with its ancient functions of legislation, justice and order.

Mr. Purdom's proposals for the transformation of British institutions into a functional social order are detailed, and involve new conceptions of politics, of city life and of the value and significance of local government, as well as a new emphasis on cultural institutions; the removal of trading services and education from eivic government gives a new aspect to regionalism. In the structure tentatively outlined, there are three functional chambers, of which the Civic Chamber would continue the specific characteristics of the House of Commons for legislation and retain its name and rules and forms. The House of Lords would be transformed into the Senate, its members appointed 
for life from among men and women distinguished in religion, science, art, letters, education, medicine, economics and civic affairs, and there would also be a Senate of Women and a Senate of Youth with consultative and advisory functions only.

The main element in the economic life of this new order would be the Economic Chamber, to which all the economic and industrial functions of the State would be transferred; it would be responsible for the reorganization of the economic life of the community, and the creation and supply and distribution of the goods and services required. This Economic Chamber would be concerned with all industries, primary and secondary, with power, transport, postal communications, agriculture, fisheries, shipping, distribution and banking. The individual, competitive, or monopolist units in every industry and service would be replaced by guilds composed of all engaged in the industry or service in whatever capacity. Through this system Mr. Purdom considers a new sense of vocation could be developed and a new standard of scientific production attained. Besides the guilds, the Chamber would work through a series of economic boards which would deal with proposals affecting the guilds or the Chamber, and consider and review regulations made by the guilds or legislation affecting them.

Parallel with the Economic Chamber, Mr. Purdom proposes a Cultural Chamber responsible for the bodily, mental and spiritual welfare of the community. This Chamber would consist of representatives of the churches and the various cultural guilds covering science, art, education, recreation, publication, etc., for which councils would also be formed through which the Chamber would work. These cultural organs, which unlike the economic organs, would not be limited to those less than forty-nine years of age, are intended to overcome the defects of specialization while enabling science and other cultural factors to exert their full humanizing influence on society.

Both in the economic and in the cultural sphere these institutions are visualized as reaching down into a system of co-ordinated local guilds in which the individual and the locality have full opportunity to make their own contribution. Similarly, while a Central Planning Board under the Minister of Planning as chairman, and formed jointly from the Economic Planning Board and the Board of Cultural Planning, would take care of the central planning required to avoid overlap and ensure consideration of all factors in national planning, it is from these same individual economic or cultural units that Mr. Purdom visualizes the beginning of effective international co-operation. The structure he contemplates for Britain would have its counterpart in the Dominions, from the political, economic and cultural chambers of which there would be formed three distinct federations: a Commonwealth Political Federation, a Commonwealth Economic Federation and a Commonwealth Cultural Federation. In addition, a Commonwealth Planning Council would be concerned with the higher direction of Commonwealth policy. The Colonies might be brought into the system as a commonwealth responsibility under a Commonwealth Colonial Council.

These Commonwealth federations are $\mathrm{Mr}$. Purdom's model of the new world institutions. Functional federation on such lines, including a federal union of States with a federal defence council, federal court, currency council, colonial council and political planning council, a federal economic union, a federal cultural union, embracing a scientific council, a council for art and a planning council for culture, and federal planning institute, first for Europe and then extending to a world union on the same lines, offers, he considers, the most hopeful solution of establishing a European and a world order giving full satisfaction to human aspirations and ideals, and in which liberty and individuality would be reconciled. It offers, too, a solution of the problem of the place of Germany in a new Europe, and many of the changes he suggests can be built on developments or institutions already brought into existence by the War.

Mr. Purdom's proposals are no doubt ambitiousmany would say visionary-but there is more to commend them than even the fact that some of his suggestions are taking crude shape under the stress of war. By far the most successful international co-operation of the last two decades has been on functional lines, and by concentrating on such developments, encouraging through them the development by education, through world planning and through cultural or economic contacts, of a widespread world consciousness, while preserving, as Prof. Carr insists, the institutions of co-operation established to serve our immediate tasks of defence or offence, it may be possible to move forward to a more concrete and formal organization when the time is ripe. Meanwhile, Mr. Purdom's proposals at least merit serious and critical examination. They indicate one way in which the points of the Atlantic Charter might be translated into action. Whether the particular proposals he details are adopted or not, no new order embodying the spirit of that declaration and safeguarding the four freedoms of mankind will ever be elaborated save by utilization of creative energy, and by readiness to face change and to accept sacrifice and responsibility. It is in that spirit alone that the immense opportunities that the War has brought can be seized and turned to the building of a new order, a new society of free men and free peoples. 